IJBPAS, December, Special Issue, 2021, 10(12): 407-419

ISSN: $2277-4998$

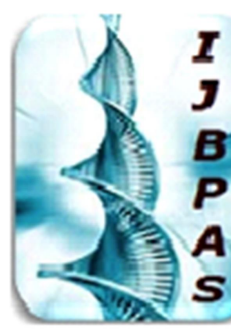

International Journal of Biology, Pharmacy and Allied Sciences (IJBPAS)

'A Bridgs Betusen Caboratory and Qandor'

Www.ijbpas.com

\title{
PHARMACOGNOSTICAL STANDARDIZATION AND PHYTOCHEMICAL STUDIES INTRIDAX PROCUMBENS L.
}

\author{
PILLAI LS* AND ABRAHAM R \\ Department of Botany, NSS College, Pandalam, Pathanamthitta \\ *Corresponding Author: Dr. Pillai Lakshmi Sreekumar; E Mail: abrus09@gmail.com \\ Received $9^{\text {th }}$ May 2021; Revised $10^{\text {th }}$ July 2021; Accepted $29^{\text {th }}$ Aug. 2021; Available online $15^{\text {th }}$ Dec. 2021 \\ https://doi.org/10.31032/IJBPAS/2021/10.12.1036 \\ ABSTRACT
}

\begin{abstract}
Standardization in medical practice is a system which ensures that every packet of medicine that is sold maintains the quality and quantity of the requisite bioactive compound and will induce the desired therapeutic effect. The most important step with respect to standardization of herbal drugs is the correct taxonomic identification of the concerned species, whether in fresh, dried or powdered state. The plant selected for the present investigation is Tridax procumbens L., belonging to the family Asteraceae. The plant originated in Central America but now occurs throughout the tropics and subtropics. A morphological study of the plant was conducted. The whole plant was shade dried and ground to fine powder and subjected to organoleptic, fluorescent and physicochemical analysis. The plant powder was subjected to Soxhlet extraction using methanol as the solvent. Phytochemical screening (Qualitative and Quantitative) of the plant extract was done according to the standard biochemical procedures. Antioxidant activity of the plant extract was tested using ABTS assay. The organoleptic analysis revealed characteristic colour, taste, odour and nature of the powder of Tridax procumbens. In fluorescence analysis, on treatment with different solvents, colour changes could be noticed in the plant powder. The results of the physicochemical analysis provided important parameters in detecting adulteration or improper handling of drugs. Qualitative and quantitative analysis in the plant confirmed the presence of many important phytochemicals such as tannins, saponins, flavonoids, terpenoids, alkaloids, simple phenolics, coumarins, quinones, acids, lignin and flavanols. Bioactivity study indicated that the antioxidant potential of the plant is comparable to that of
\end{abstract}


the standard Trolox. The present work will be useful in the synthesis of new drugs of pharmaceutical importance from Tridax procumbens.

\section{Keywords: Tridax procumbens, Asteraceae, Organoleptic, Phytochemical, antioxidant INTRODUCTION}

Medicinal plants have served through ages as a constant source of medicaments for the exposure of a variety of diseases. The history of herbal medicines is almost as old as human civilization. People have depended on nature from time immemorial for their basic needs such as food, clothing and shelter ${ }^{1}$. Various plant products have medicinal properties ${ }^{2}$. From generation to generation the collected knowledge of medicinal plants was passed on through stories, paintings, writings etc. Overtime, the knowledge of medicinal plants evolved into well-known traditional medicine systems ${ }^{3}$.

Pharmacognosy is a vital link between the traditional and allopathic systems of medicine. It provides a system wherein the active principles of crude drugs derived from natural origin can be dispensed, formulated and manufactured in dosage forms acceptable to allopathic system of medicine ${ }^{4}$. Pharmacognostical standardization is the study of physical, chemical and biological properties of natural drugs, drug substances or potential drugs through prescribed standards, constant parameters, definitive qualitative and quantitative values that carry an assurance of quality, efficacy, safety and reproducibility ${ }^{5,6}$.

The hidden potential of medical activities can be decisive in the treatment of present and future studies ${ }^{1}$. The natural drugs from plants have lower side effects and risks. They are more cost effective. Majority of plant derived natural products remain undiscovered for their pharmacological activity ${ }^{2}$. There is a promising future of medicinal plants as there are about half a million plants around the world and most of them are yet to be investigated for their medical activities. The large number of medicinal plants used by traditional healers of remote villages and primitive aborigines has not been completely documented for their phytochemical constituents and pharmacological activities. Tridax procumbensbelonging to the family Asteraceae is one such plant used in traditional healthcare systems.

The plant selected for the present study, Tridax procumbens, belongs to the family Asteraceae (Compositae). The plant is a straggling hispid herb with much cut leaves, yellow flowers and achenes with feathery pappus ${ }^{7}$. It is a native of tropical 
America. It has been introduced to tropical, subtropical and mild temperate regions of the world ${ }^{8}$. In India, the plant has been traditionally used for wound healing and as an anticoagulant, antifungal and insect repellent. The leaf extract is applied directly on the wounds. In folklore medicines the leaf extracts are used for infectious skin diseases. It is used in Ayurvedic medicine for liver disorders, hepatoprotection, gastritis and heartburn. Local healers in different parts of India use Tridax procumbens for treating boils, blisters and cuts ${ }^{9}$. It is also used for malaria, stomach ache, high blood pressure, haemorrhage and to prevent hair fall ${ }^{10}$.

The aim of the present work was a systematic study on the pharmacognostic, chemical composition and biological activity to ascertain and validate the ethnomedicinal and pharmaceutical potential of Tridax procumbens.

\section{MATERIALS AND METHODS}

\section{Plant material}

The plant selected for the study, Tridax procumbens was collected from Pandalam, Pathanamthitta. The aerial parts of the plant were used for the project work.

\section{A. Morphological study}

The morphology of the species Tridax procumbens was studied using taxonomic kit based on qualitative and quantitative characters. The observations were recorded.

\section{B. Powder analysis}

Fresh plant of Tridax procumbens was collected in polythene bag. Dirt was removed from the collected material. It was shade dried and then powdered in an electric grinder and sieved with fine mesh sieve. The powder was then used for the organoleptic study and solvent extraction.

\section{Organoleptic study}

Organoleptic (literally "impression on the organs") refers to the evaluation by means of the organs of sense and includes the macroscopic appearance of the plant material, its colour, odour, and taste, occasionally the sound of 'snap' of its fracture and the 'feel' of the powder to the touch ${ }^{11}$. The plant powder characteristics like the colour, odour, taste and nature were evaluated.

\section{Fluorescence analysis}

The crude drug powder was treated as such with eight different reagents. The solvents used were water, hydrochloric acid, sulphuric acid, nitric acid, sodium hydroxide, acetic anhydride, methanol and acetone. Each solution was loaded on an activated thin gel layer slide and the fluorescence under normal light, short UV (256 nm) and long UV (365 nm) was observed $^{12}$.

\section{Physicochemical characterization}




\section{Different \\ physicochemical}

parameters were determined according to the official methods and guidelines on quality control for medicinal plant materials.

i).Loss on drying ${ }^{13}$

ii).Foaming index 14

iii).Swelling index ${ }^{14}$

iv).Foreign matter ${ }^{15}$

v). $\mathrm{pH}^{16}$

\section{Phytochemical screening}

\section{Preparation and yield of extract ${ }^{15}$}

About $15 \mathrm{~g}$ of the powdered plant material was subjected to extraction by Soxhlet apparatus using $100 \mathrm{ml}$ methanol. The extract was concentrated under reduced pressure and preserved in refrigerator until further use. The percentage of the crude extract was determined using the following equation.

Percentage yield $(\%)=\frac{\text { Weight of the crude extract }}{\text { Weight of the sample }} \times 100$

\section{Qualitative analysis}

Different phytochemical constituents were tested using standard biochemical procedures ${ }^{17}$.

Tannins

Saponins

Flavonoids

Alkaloids

Terpenoids

Phlobatannins

Glycosides

Simple phenolics
Coumarins

Quinones

Acids

Flavanols

Lignin

Steroids

Gums and Mucilage

\section{Quantitative analysis}

i). Determination of Alkaloids ${ }^{17}$

ii). Determination of phenols ${ }^{18}$

D. Bioactivity study - antioxidant activity

\section{ABTS [2, 2'-Azino-bis ethylbenzothiazoline-6-sulfonic acid)] radical scavenging activity ${ }^{19}$}

Trolox standards of different concentrations were prepared. The ABTS substrate working solution was prepared by adding $25 \mu \mathrm{l}$ of $3 \%$ hydrogen peroxide solution to $10 \mathrm{ml}$ of ABTS substrate solution. The assays were prepared in 96 wells plate. In the wells for the Trolox standard, $10 \mu \mathrm{l}$ of Trolox and $20 \mu \mathrm{l}$ of myoglobin working solution were added. In the wells for the test samples, $10 \mu \mathrm{l}$ (20-80 $\mu \mathrm{g} / \mathrm{ml}$ concentration) of plant extracts and $20 \mu \mathrm{l}$ of myoglobin working standard were added. Then the solution was incubated for 5 minutes at room temperature. The stop solution $(100 \mu \mathrm{l})$ was added to each well. The end point absorbance was read at 405 $\mathrm{nm}$ using a plate reader.

Percentage of inhibition $(\%)=\frac{\text { Abs control }- \text { Abs sample }}{\text { Abs control }} \times 100$ 


\section{RESULTS}

\section{A. Morphological study}

An account of the morphological characters of Tridax procumbensis given below (Table 1):

\section{B. Powder analysis}

1. Organoleptic study

The colour of the plant powder showed the following characters:

Colour: Light olive green

Smell: Astringent

Taste: Lightly bitter

Texture: Rough

\section{Fluorescence analysis}

The dry powder was subjected to fluorescence analysis with different reagents in normal light, short UV and long UV. The colour changes are summarized (Table 2):

\section{Physicochemical characterization}

A total of five physicochemical parameters were evaluated in Tridax procumbens (Table 3). The plant moisture content was reported in low amounts. Forming index was more than $100 \mathrm{ml}$. The $\mathrm{pH}$ was found to be 6.5 . Foreign matter and swelling were not observed.

\section{Phytochemical screening}

\section{Yield of extract}

The methanol extract was prepared by Soxhlet extraction. The yield of the methanol extract was $3.8 \%$.

\section{Qualitative analysis}

A total of 15 phytochemicals were qualitatively analysed in methanol extract of the plant. Most of the compounds were present in the extract. Phlobatannins, glycosides, steroids, gums and mucilage were absent in the plant extract. The phytochemical screening tests are provided (Table 4).

\section{Quantitative analysis}

The quantitative analysis of two phytochemicals was done in the methanol extract of Tridax procumbens (Table 5) by standard procedures. The amount of alkaloid was higher than the amount of phenols.

\section{Bioactivity study - antioxidant activity}

\section{ABTS assay}

The scavenging activity of the extract was compared with that of Trolox standard and percentage inhibition was calculated. The percentage inhibition of the ABTS radical by the methanol extract of the plant increased with increase in concentration. In this assay, by Probit analysis the methanol extract of Tridax procumbens had good ABTS scavenging activity with $\mathrm{IC}_{50}$ value of $42 \mu \mathrm{g} / \mathrm{ml}$. The $\mathrm{IC}_{50}$ value of the standard Trolox was $38 \mu \mathrm{g} / \mathrm{ml}$. The results are shown in Table 6. 
Table 1: Morphological Characters Of Tridax procumbens

\begin{tabular}{|c|c|c|c|}
\hline CHARACTER & \multicolumn{3}{|c|}{ DESCRIPTION } \\
\hline Habit & \multicolumn{3}{|c|}{ Perennial herb } \\
\hline Stem & \multicolumn{3}{|c|}{$\begin{array}{c}\text { The herbaceous stem up to } 50 \mathrm{~cm} \text { long may be prostrate to ascending and } \\
\text { trailing. }\end{array}$} \\
\hline Leaves & \multicolumn{3}{|c|}{ Leaves opposite, Inciso-dentate or pinnatisect. } \\
\hline Inflorescence & \multicolumn{3}{|c|}{$\begin{array}{l}\text { A medium-sized centripetal head of many heterogamous flowers (tubular and } \\
\text { rayed), sessile on the dilated top of the flat or convex peduncle (receptacle), } \\
\text { enclosed in an involucre of whorled bracts. Involucre campanulate, few-seriate } \\
\text { outer broad, herbaceous, inner scarious, paleae membranous }\end{array}$} \\
\hline Flower & \multirow{4}{*}{\multicolumn{3}{|c|}{$\begin{array}{l}\text { Epigynous; ray flowers female, fertile; disc flowers bisexual, fertile } \\
\text { Calyx tube adnate to the ovary; Pappus of short or aristate feathery bristles } \\
\text { Corolla of two forms : (i) tubular or campanulate with } 5 \text { lobes; (ii) ligulate (ray } \\
\text { or 2-labiate with the outer lip large 3-lobed, the inner small 2-lobed } \\
\text { Stamens 5, inserted within the corolla tube; filaments free, basifixed, anther } \\
\text { bases with short acute auricles. }\end{array}$}} \\
\hline Sepal & & & \\
\hline Petal & & & \\
\hline Androecium & & & \\
\hline Gynoecium & \multicolumn{3}{|c|}{$\begin{array}{c}\text { Bicarpellary, syncarpous, basal placentation, ovule solitary, style arms hairy, th } \\
\text { tips subulate. }\end{array}$} \\
\hline $\begin{array}{l}\text { Fruit } \\
\text { Seed }\end{array}$ & \multicolumn{3}{|c|}{$\begin{array}{c}\text { Dry indehiscent achene, turbinate or oblong, silky } \\
\text { Seed erect, testa membranous, }\end{array}$} \\
\hline \multicolumn{4}{|c|}{ Table 2: Fluorescence Analysis Of Tridax procumbens } \\
\hline Powder + Reagent & $\begin{array}{c}\text { Visible } \\
(400-800 \mathrm{~nm}) \\
\end{array}$ & $\begin{array}{l}\text { UV short } \\
(256 \mathrm{~nm})\end{array}$ & $\begin{array}{l}\text { UV long } \\
(365 \mathrm{~nm})\end{array}$ \\
\hline Powder as such & Dark green & Dark green & Black \\
\hline Powder $+\mathrm{H}_{2} \mathrm{O}$ & Green & Green & Black \\
\hline Powder + Conc. HCl & Green & Dark green & Black \\
\hline Powder + Conc. $\mathrm{H}_{2} \mathrm{SO}_{4}$ & Black & Black & Black \\
\hline Powder + Conc. $\mathrm{HNO}_{3}$ & Reddish orange & Green & Black \\
\hline Powder + NaOH & Black & Dark green & Black \\
\hline Powder + Acetic anhydride & Dark green & Dark green & Black \\
\hline Powder + MeOH & Dark green & Dark green & Black \\
\hline Powder + Acetone & Dark green & Dark green & Black \\
\hline
\end{tabular}

Table 3: Physicochemical Characters of Tridax procumbens

\begin{tabular}{cc} 
Table 3: Physicochemical Characters of Tridax procumbens \\
\hline PARAMETERS & VALUES \\
\hline Loss on drying & $9.80 \% \pm 0.02$ \\
Foaming index & $>100 \mathrm{ml}$ \\
Swelling index & NIL \\
Foreign matter & NIL \\
pH & 6.5 \\
\hline
\end{tabular}

4: Phytochemicals Tested In Tridax procumbens

\begin{tabular}{ccc}
\hline S.NO. & PHYTOCHEMICALS & PRESENT/ABSENT \\
\hline $\mathbf{1 .}$ & Tannins & + \\
$\mathbf{2 .}$ & Saponins & + \\
$\mathbf{3 .}$ & Flavonoids & + \\
$\mathbf{4 .}$ & Alkaloids & + \\
$\mathbf{5 .}$ & Terpenoids & - \\
$\mathbf{6 .}$ & Phlobatannins & - \\
$\mathbf{7 .}$ & Glycosides & + \\
$\mathbf{8 .}$ & Simple Phenolics & + \\
$\mathbf{9 .}$ & Coumarins & + \\
$\mathbf{1 0 .}$ & Quinones & + \\
$\mathbf{1 1 .}$ & Acids & + \\
$\mathbf{1 2 .}$ & Flavanols & + \\
$\mathbf{1 3 .}$ & Lignin & - \\
$\mathbf{1 4 .}$ & Steroids & - \\
$\mathbf{1 5 .}$ & Gums and mucilage & \\
\hline
\end{tabular}

Table 5: Quantitative Estimation Of Tridax procumbens

\begin{tabular}{ccc}
\hline S. No. & PHYTOCHEMICALS & AMOUNT $(\mathbf{m g} / \mathbf{g})$ \\
\hline 1. & Alkaloids & 102 \\
2. & Phenols & 58 \\
\hline
\end{tabular}


Table 6: ABTS Antioxidant Assay Of Tridax procumbens Extract

\begin{tabular}{cccc}
\hline S. No. & $\begin{array}{c}\text { Concentration of } \\
\text { extract }(\mu \mathrm{g} / \mathrm{ml})\end{array}$ & $\begin{array}{c}\text { Trolox (percentage of } \\
\text { inhibition) }(\%)\end{array}$ & $\begin{array}{c}\text { Plant extract } \\
\text { (percentage of } \\
\text { inhibition) }(\%)\end{array}$ \\
\hline 1. & 20 & 35 & 32 \\
2. & 40 & 55 & 52 \\
3. & 60 & 80 & 76 \\
4. & 80 & 96 & 92 \\
\hline
\end{tabular}

\section{DISCUSSION}

Pharmacognostic standardization ensures that every packet of drug that is sold in the market maintains the quality and quantity of the requisite bioactive compound and will induce the desired therapeutic effect. It serves number of purposes including batch to batch consistency, determine correct dosage amount or extract per dosage unit, positive control to indicate possible loss or degradation during manufacturing ${ }^{20}$.

The morphological characterization is an important first step towards correct identification of plant material. The identification is by macroscopic comparison with authentic material or accurate description of authentic herbs ${ }^{21}$. The pharmacognostic standardization of Tridax procumbens was initiated with detailed analysis of the plant's morphological characters. The plant has several unique vegetative and reproductive characters such as straggling hispid stem, inciso-dentate leaves, heterogamous capitulum with yellow centred white threetoothed ray florets and yellow disc florets and achenes with feathery pappus (Table 1).

Organoleptic evaluation is the conclusion drawn from impressions on organs of senses ${ }^{4}$. The colour, smell, taste and texture of the powder were analysed. Tridax procumbens plant powder has light olive green colour, astringent smell, slightly bitter taste and rough texture. The characteristic astringent smell is an important diagnostic organoleptic character of the plant.

The fluorescence study of Tridax procumbens was attempted. The crude powder was treated with various reagents and they revealed characteristic fluorescence at $256 \mathrm{~nm}$ and $365 \mathrm{~nm}$ wavelengths (Table 2). The fluorescence analysis is adequately sensitive and enables the precise and accurate determination over a satisfactory concentration range without several time-consuming dilution steps prior to analysis of pharmaceutical samples ${ }^{22}$. The physical or physicochemical parameters are useful in establishing quality profile of a crude drug and constitute an important component of qualitative evaluation ${ }^{4}$. They help in 
detecting adulteration or improper handling of drugs ${ }^{23}$. The physicochemical parameters in Tridax procumbens were analysed (Table 3).

Low moisture content $(<14 \%)$ is preferable for an herbal drug. It prevents the decomposition of crude drugs due to chemical change or microbial contamination ${ }^{4}$. It discourages the growth of microbes such as mites, bacteria, fungi or yeast ${ }^{23}$. The moisture content of Tridax procumbens plant was $9.80 \%$ (Table 3), which is much lower than that in many other plants. Low moisture is an important parameter which determines the quality of herbal drug. The foaming index of Tridax procumbens was found to be $>100 \mathrm{ml}$ indicating the presence of saponins in the plant. The swelling index was absent in the plant suggesting the absence of gums and mucilage. The $\mathrm{pH}$ of $5 \%$ aqueous solution of the plant was 6.5. The acidic nature of the powder may be due to presence of acidic salts (Table 3). The presence or absence of foreign matter is another physicochemical parameter determining the purity of the drug. The permissible limit of foreign matter is not more than $2 \%$. Therefore, regulations support that drug containing appreciable amount of potent foreign matter, animal excreta, insects or moulds should be rejected even if the percentage of such substance would be insufficient to cause any harm ${ }^{24}$. Foreign matter was absent in the crude plant powder of Tridax procumbens (Table 3).

The phytochemical screening is a part of chemical evaluation. It is useful in detection of adulteration and establishing the chemical profile of the crude drug. The purity of the crude drug is ascertained by quantitative estimation of active chemical constituents present in them ${ }^{4}$. One of the major steps in phytochemical screening is extraction. This technique which involves the use of different solvents is commonly employed for separation of active substance from crude drug. Dried powdered material is commonly used for extraction. The extraction can be performed by repeated maceration with agitation, percolation or by continuous extraction using Soxhlet extractor ${ }^{4}$. In the present study, the powdered aerial parts of Tridax procumbens were subjected to Soxhlet extraction using methanol. The yield of the concentrated extract was $3.8 \%$

The methanolic extract of Tridax procumbens was subjected to preliminary phytochemical screening. The chemicals present were tannins, saponins, flavonoids, terpenoids, alkaloids, simple phenolics, coumarins, quinones, acids, lignin and flavanols (Table 4). Quantitative estimation of alkaloids and phenols were carried out using standard procedures. The 
compounds were found to be in considerable amounts (Table 5).

Alkaloids are nitrogen containing cyclic organic compounds. Alkaloids are pharmaceutically significant. They possess analgesic, anti-malarial, antispasmodic, anticancer, antimicrobial, antihypertensive, antioxidant, anti-inflammatory, sedative and cough suppressant properties ${ }^{25}$. Simple phenolic compounds have a monocyclic aromatic ring with an alcoholic, aldehyde or carboxylic group. They have analgesic, anti-bacterial, anti-inflammatory and local anaesthetic activities ${ }^{25}$. Phenols protect human body from the oxidative stress which may cause many disease including cancer and cardiovascular problems ${ }^{26}$.

Tannins are water soluble plant polyphenols that precipitate proteins. They have various physiological and therapeutic effects like anti-irritant, antimicrobial, antibacterial, antiparasitic, antiinflammatory and wound healing effects ${ }^{27}$. Coumarins are well known for their antithrombotic, anti-inflammatory and vasodilatory activities. They also have anticoagulant, rodenticide, antiviral and antimicrobial effects. The quinones have limited pharmaceutical significance; however, they exhibit antimicrobial and cytotoxic properties ${ }^{28}$.

Flavonoids are low molecular weight polyphenolic compounds. Flavonoids are indispensable components in a variety of nutraceutical, pharmaceutical and medicinal applications. This is attributed to their antioxidative, anti-inflammatory, antimutagenic, anti-allergic, anti-diarrhoeal and anticarcinogenic properties coupled with their capacity to modulate key cellular enzyme function ${ }^{29}$.Terpenoids have antitumor and anticancer, antiinflammatory, analgesic, antiviral and antibacterial activities. It is useful in the treatment of arthritis, skin allergies and gastric ulcers ${ }^{30}$. Saponins have great pharmaceutical importance as they have antioxidant, anti-diarrhoeal, anticancer, wound healing, expectorant, antiviral, antimicrobial properties and are also used to treat hypercholesterolemia, cardiovascular disease and hyperglycemia ${ }^{31}$.

The antioxidant activity of putative antioxidants has been attributed to various mechanisms such as, the prevention of chain ignition, the binding of transition metal ion catalysts, decomposition of peroxides, the prevention of continued hydrogen abstraction, the reductive capacity and radical scavenging ${ }^{32}$. ABTS assay has been the most widely employed method for estimating antioxidant activity. This assay is based on the spectrophotometric measurement of ABTS cation radical $\left(\mathrm{ABTS}^{\circ+}\right)$ concentration 
changes resulting from the $\mathrm{ABTS}^{\circ+}$ reaction with antioxidants. The principle of the assay is the formation of ferryl myoglobin radical from metmyoglobin and hydrogen peroxide, which oxidizes ABTS to generate radical cation, $\mathrm{ABTS}^{\circ+}$. This radical cation is a soluble chromogen that is green in colour and can be measured by absorbance at $405 \mathrm{~nm}$. Antioxidants suppress this reaction by various mechanisms and inhibit the formation of the coloured ABTS radical cation. The inhibition percentage of the ABTS radical cation formation by the added antioxidant sample at a fixed time point is quantified as the result ${ }^{33}$.

The methanol extract of Tridax procumbens suppressed the production of radical cation, with proportional decrease in colour intensity. The scavenging of cation was in a concentration dependent manner, where the percentage inhibition increased with an increase in concentration.

The present study indicates the potential utilization of Tridax procumbens plant singly or in certain formulations to treat several diseases or disorders of humans and livestock. Tridax procumbens is a weed which can be easily grown in available areas for medicinal purposes. The results of antioxidant study indicated that $T$. procumbens was potentially active and comparable to Trolox, so it could be used as a potent source for the cancer chemoprotective therapy and would be an optimistic scaffold for prospective in vivo studies. The study also showed that Tridax procumbens can be investigated further as a possible new source of natural antioxidant in the food, neutraceuticals and cosmetic industry.

\section{CONCLUSION}

The scientific investigation of traditional herbal remedies may provide valuable data for the development of alternative drugs and therapeutic strategies. The present study dealt with the pharmacognostic standardization and phytochemical evaluation of the plant Tridax procumbens (Asteraceae). The data obtained in the present work will be useful in the synthesis of new drugs of pharmaceutical importance from Tridax procumbens. The in vitro antioxidant studies must be followed by clinical trials in man. The toxicity should be evaluated before advocating the extract of Tridax procumbens as potential drugs. Traditionally, it was the decoction and macerates of Tridax procumbens that were used medicinally. The antioxidant activity of the plant may be due to the synergistic action of the phytochemicals present in the methanol extract. The findings provide scientific evidence to support traditional medicinal uses and indicate a promising 
potential for the development of lead compounds from the plant.

\section{ACKNOWLEDGEMENTS}

The authors are thankful to Dr.Sandhya P., Head of the Department, NSS College Pandalam for providing all the required facilities for the conduct of this project work.

\section{CONFLICT OF INTEREST}

The authors declare that they have no conflict of interest

\section{REFERENCES}

[1] Dar RA, Shahnawaz M, and Qazi PH: General overview of medicinal plants: A review. The Journal of Phytopharmacology2017; 6(6): 349351.

[2] Raskin I, Ribnicky DM, Komarnytsky S, Ilic, N, Poulev A, Borisjuk N, Brinker A, Moreno DA, Ripoll C, Yakoby N, O’Neal JM, Cornwell T, Pastor I and Fridlender B: Plants and human health in the twenty-first century. Trends in Biotechnology2003; 20(12): 52231.

[3] Mamedov N and Craker L: 2012. Man and medicinal plants: A short review. Acta Horticulturae, 2012; 964: 181-190.

[4] Kokate CK, Purohit AP and Gokhale SB: Pharmacognosy. Nirali Prakashan, Pune.2012.
[5] Sarker SD: 2012. Pharmacognosy in modern pharmacy curricula. Pharmacognosy Magazine2012; 8(30): 91-92.

[6] Kunle OF, Egharevba $\mathrm{HO}$ and Ahmadu PO: Standardization of herbal medicines - A review. International Journal of Biodiversity and Conservation2012; 4(3): 101112.

[7] Gamble JS: Flora of the Presidency of Madras. Volume II. Neeraj Publishing House, Delhi. 1934:658 -659 .

[8] Kale SS and Deshmukh AS: Tridax procumbens: A medicinal gift of nature. Asian Journal of Research in Biological and Pharmaceutical Sciences2014; 2(4): 159-162.

[9] Bhagat VC and Kondawar MS: A comprehensive review on phytochemistry and pharmacological use of Tridax procumbens Linn. Journal of Pharmacognosy and Phytochemistry2019; 8(4): 1-10.

[10] Grace B, Manjamalai A, Varghese SS, and Haridas A: Antifungal, Anti-inflammatory and GC-MS Analysis for bioactive molecules of Tridax procumbens L. leaf. Asian Journal of Pharmaceutical 
and Clinical Research, 2012; 5(1):

139-145.

[11] Wozniak W, Radajewska B, Reszelska-Sieciechowicz A and Dejwor I: Sugars and acid content influence organoleptic evaluation of fruits of six strawberry cultivars from controlled cultivation. Acta. Horticulturae 1997; 439: 333-336.

[12] Chase $\mathrm{CR}$ and Pratt R: Fluorescence of powdered vegetable drugs with particular reference to development of a system of identification. Journal of the American Pharmaceutical Association1949; 38(6): 324-331.

[13] Indian Pharmacopoeia: Volume II. Part I. The Controller of Publications, CSIR, New Delhi.1992.

[14] WHO: Quality control methods for medicinal plant materials. OrganisationMondiale de la Sante, Geneva.1992; 9: 22-34.

[15] Indian Pharmacopoeia: Volume II. Part II. The Controller of Publications, CSIR, New Delhi. 1996: 53-54.

[16] Iqbal D, Pawar RK and Sharma RK: Physico-chemical standardization of Buteamono sperma (Lam.) Kuntze (Palasha): An Ayurvedic drug. International
Journal of Pharmaceutical Quality Assurance, 2010; 2(1): 49-51.

[17] Harborne JB: Phytochemical methods: a guide to modern techniques of plant analysis. Chapman and Hall, London. 1973.

[18] Spanos GA and Wrolstad RE: Influence of processing and storage on the phenolic composition of Thompson seedless grape juice. Journal of Agricultural and Food Chemistry1990; 38: 1565-1571.

[19] Miller NJ and Rice-Evans CA: Factors influencing the antioxidant activity determined by the ABTS ${ }^{\cdot+}$ radical cation assay. Free Radical Research, 1997; 26(3): 195-199.

[20] Gurav N, Solanki B, Pandya K and Patel P: Physicochemical and antimicrobial activity of single herbal formulation-capsule, containing Emblica officinalis Gaertn. International Journal of Pharmacy and Pharmaceutical Sciences2011; 3(5): 383-386.

[21] Houghton PJ: Establishing identification criteria for botanicals. Drug Information Journal, 1998; 32(2), 461-469.

[22] Pimenta AM, Montenegro MC, Araujo AN and Martinez JC: 2006. Application of sequential 
injections

analysis

to

pharmaceutical analysis. Journal

of Pharmaceutical Biomedical

Analysis 2006; 40: 16-34.

[23] Pande J, Padalia H, Donga S and Chanda S: Pharmacognostic, physicochemical and phytochemical studies of Andrographis echioides Nees. And Tridax procumbens L. leaf and stem. The Pharma Innovation Journal. 2018; 7(6): 303-315.

[24] WHO: WHO guidelines for assessing quality of herbal medicines with reference to contaminants and residues. 2007; $\mathrm{p}: 19$.

[25] Gurib-Fakim A: Medicinal plants: Traditions of yesterday and drugs of tomorrow. Molecular Aspects of Medicine 2006; 27(1): 1-93.

[26] Robards K, Prenzler PD, Tucker G, Swatsitang P and Glover W: Phenolic compounds and their role in oxidative processes in fruits. Food Chemistry1999; 66(4): 401436.

[27] Westendarp H: Effects of tannins in animal nutrition. Deutsche tierarztliche Wochenschrift, 2006; 113: 264-268.

[28] Cowan MM. Plant products as antimicrobial agents. Clinical
Microbiology Reviews 1999; 12(4): 564-582.

[29] Panche AN, Diwan AD and Chandra SR: Flavonoids: An overview. Journal of Nutritional Science 2016; 5 (47).

[30] Mahato SB and Sen S: Advances in triterpenoid research. Phytochemistry1997; 44(7): 11851236.

[31] Shi J, Arunasalam K, Yeung D and Kakuda Y: Saponins from edible legumes: Chemistry, processing and health benefits. Journal of Medicinal Food2004; 7(1): 67-78.

[32] Biswas M, Haldar PK and Ghosh AK: Antioxidant and free-radicalscavenging effects of fruits of Dregea volubilis. Journal of Natural Science, Biology and Medicine2010; 1(1):29-34.

[33] Kambayashi Y, Binh NT, Asakura HW, Hibino Y, Hitomi Y, Nakamura $\mathrm{H}$ and Ogino $\mathrm{K}$ : Efficient assay for total antioxidant capacity in human plasma using a 96-well microplate. Journal of Clinical Biochemistry and Nutrition2009; 44: 46-51. 